\title{
The Dynamics of the Role of the Nahdlatul Ulama Social Movement in Responding to Social Change
}

\author{
Saepulah ${ }^{*}$, Lina Herlina ${ }^{2}$, Unang Fauzi ${ }^{3}$ \\ 123UIN Sunan Gunung Djati Bandung \\ * Corresponding author E-mail: drsaepulah@gmail.com
}

\begin{abstract}
The purpose of this study is to uncover sociological and cultural conclusions about community dynamics in various dimensions. The method used in this research is to conduct a literature review relating to the historical trajectory of Nahdhatul Ulama (NU) as a primary data source. Besides, an analysis of various data and information obtained from literature and journals as a source of secondary data. Based on the results of data and information processing, it is concluding that $\mathrm{NU}$, as a social organization in the religious, social movement, has a significant contribution to the socioreligious dimension. Contributions include spiritual, social, educational, environmental, and economic preservation, including improving communication between scholars, improving the quality of Islamic schools, selecting books studied in Islamic boarding schools, and establishing bodies to support agricultural activities and Muslim trade.
\end{abstract}

Keywords: Contribution, Improvement, Nahdlatul Ulama, Religious

\section{INTRODUCTION}

Nahdlatul Ulama (NU) is the largest Islamic organization in Indonesia. As a mass-based organization, $\mathrm{NU}$ is unique and not the same as other organizations. One indicator of the uniqueness of this mass organization is the strong influence of public founders in their circles, both in the form of the importance of normative fatwas and phenomenological views. The force turned out to have a significant impact on the shift in orientation from the primordial to practical interests. This is indicated by the emergence of new political parties from the $\mathrm{NU}$ organization, which initially aimed to accommodate the interests of NU (Herdiansah, 2017). But in the subsequent development, the presence of political parties formed by $\mathrm{NU}$ did not adequately represent the interests of the NU masses.

The undeniable reality is that public figures from $\mathrm{NU}$ circles are more rooted than political identity(Syukur, 2011). This condition has been exploited freely by the leaders of political parties through legislative lobbying efforts to several NU figures. The implication can be seen from the distribution of $\mathrm{NU}$ cadres in various political parties, both nationalist and religious, both as opposition parties and supporters of the authorities.

Other facts outside the government, the role of NU organizations both as an institution and the strength of the masses have contributed significantly to efforts to counter ideology. In the sociocultural field, NU has made quite progressive breakthroughs, including improving communication between scholars, improving the quality of Islamic schools, selecting books(Luthfi, 2017). NU's gait in conducting a solemn service to this nation, was marked as a representation of NU's pace in balancing social dynamics in society.

NU's movement in an effort to respond to this social phenomenon has been widely stated by previous researchers, such as Lutfi who explained about NU's efforts in consolidating its cadres

\footnotetext{
* Copyright (c) 2020 Saepulah et.all

This work is licensed under a Creative Commons Attribution-ShareAlike 4.0 International License.
} 
through mentoring human resources, developing and improving institutional quality, as well as conducting a comprehensive analysis of the literature that is often used in the NU mass environment. Then in his research, Syukur explained the charisma of NU figures who have high selling power in life and political events both at the local and national levels. Herdiansyah explained the movement and progress of NU in the political field. The difference between this research and previous research lies in the focus of study that leads to social and religious movements. The consideration is because the problems faced by this nation are more visible impacts. While previous research focused more on institutional and policy issues, it did not touch the effect of the system.

\section{METHODOLOGY}

This research uses a sociological analysis approach, which is studying the literature and analyzing those related to the NU religious movement. In this study, researchers continue to move between the three components of analysis with data collection activities during the data collection process and also after the data collection takes place. Consistent with this analysis technique, if there is a lack of data for the stability of the conclusions, the researcher will return to the location to collect data supporting the end.

\section{DISCUSSION AND RESULTS}

NU was founded on January 31, 1926, in Surabaya by a group of prominent scholars who were mostly leaders of the pesantren. Among those present at the meeting of the leaders of the pesantren were K.H. Hasyim Asy'ari, K.H. Wahab Hasballah, K.H. Bisri Syamsuri, K.H. Ridwan, K.H. Nawawi, and K.H. Doromuntaha(Ridwan, 2008). NU aims to fight for traditional Islam, especially the pesantren world. In the 1920s, it was indeed rapid Islamic modernism and succeeded in attracting many Muslims in these areas.

If in Egypt and Turkey the reform movement arises due to political awareness of their backwardness from the West, in Saudi Arabia the Wahabi movement appears to wrestle with the internal problems of Muslims themselves, namely reform of monotheism and conservation in the field of law which they say has been undermined by khurafat and polytheism which hit Muslims. While in Indonesia, there were growing national and religious social organizations aimed at advancing the lives of the people, such as Budi Utomo (May 20, 1908), the Islamic Society (November 11, 1912), and then followed by Muhammadiyah (November 18, 1912). These things have aroused the enthusiasm of some Indonesian Muslim youth to form educational and da'wah organizations, such as Nahdatul Wathan (Resurrection of the motherland), and Taswirul Afkar (portrait of thought). The two organizations were jointly initiated by K.H. Abdul Wahab Hasbullah and Mas Mansur. This organization was the forerunner of the birth of NU(Paralihan, 2019).

At the same time, the abolition of the Caliphate in Turkey and the fall of the Hijaz into the hands of Ibn Sa'ud, who adhered to Wahabiyah in 1924, triggered open conflict in Indonesian Muslim society. In 1802 in Minangkabau, an understanding of Islam emerged with a Wahabi style led by H. M. Poor, and this led to the pros and cons of the traditions. Also, in 1913 Ahmad Surkati founded Al-Irshad, and in 1923 PERSIS was established. Martin Van Bruinessen said that the birth of NU was a defensive reaction to the various activities of the reformist group(Van Bruinessen \& Wajidi, 1994). 
These changes disturbed most Javanese scholars, including K.H. Wahab Hasbullah. He and like-minded scholars realized and made efforts to fight the movement. K.H. Hasyim Asy'ari (18711947) a Kyai from the Pesantren Tebuireng, Jombang, East Java, who was the most respected Javanese scholar, agreed to their request to form NU in 1926 and he became its first chairman or Ro'is Akbar. NU developed rapidly during the period before the world war. In 1933, membership was recognized to be around 40,000, and in 1938 it increased to 100,000 with 99 registered branches. In 1934, Ansor's youth wing organization was founded. Four years later (1938), Muslimat $\mathrm{NU}$ was formally established together with the establishment of the Ma'arif Educational Institute. Initially, NU was established as jam'iyyah diniyah or religious organizations. The organization will serve religious, social, educational, and economic activities, including increasing inter-cleric communication, improving the quality of Islamic schools, selecting books to be studied in Islamic boarding schools, and establishing bodies to support agricultural activities and Muslim trade(Bukhari, 2014).

During the colonial period, both the Dutch occupation (1926) - 1942) and the Japanese occupation (1942-1945). Since $1930 \mathrm{NU}$ joined with Islamic organizations opposing colonial government regulations, which were considered to be hostile to Islam. Besides that, NU also supported the formation of GAPPI (Association of Indonesian Political Parties) and its call to form the Indonesian parliament in 1939 (Van Bruinessen \& Wajidi, 1994). At the beginning of its establishment period, NU prioritized the formation of unity among Muslims to oppose the Dutch colonial(Hemay \& Munandar, 2016). To unite Muslims, K.H. Hasyim Asy'ary launched an invitation to join by establishing a confederation, Majlis Islam A'la Indonesia (MIAI), which was formed in 1937. The founding of this organization basically invited all components of the nation to fight against the Dutch invaders with a cultural struggle pattern to achieve independence.

During the Japanese occupation, NU, as a religious organization, also opposed all forms of colonialism, including K.H. Hasyim Ash'ary (as Rois Akbar at the time), was jailed for refusing to honor the Japanese emperor by bowing to the east at certain times. More specifically, NU conducted a series of struggle programs. The struggle program is directed to fulfill three main objectives, viz: 1.) Rescuing Islamic aqidah from Shintoism, especially the Seikerei teachings imposed by Japan. 2.) Tackling the economic crisis as a result of the East Asian war in collaboration with all components of the National Movement to break away from all forms of colonialism. 3.) In October 1943, a federation of Islamic organizations was formed to unite Muslims, which was named Majlis Syuro Muslimin Indonesia (MASYUMI)(Paralihan, 2019).

In August 1944, NU initiated the formation of Shumubu (Office of Religious Affairs) for the intermediate level, and the Office of Religious Affairs for the regional level was named Shumuka. Furthermore, since 1945, NU entered formal politics as an organizational element of the Masyumi Islamic party. Next, because Masyumi was dominated by modernists, in 1952, NU left Masyumi. Then NU transformed itself into an independent party into the third-largest election participant in the 1955 election by obtaining 18\% of the vote (only 4\% difference in the first place). NU maintained this level of support in the next election in 1971. It also participated in each cabinet from 1953-1971(Van Bruinessen \& Wajidi, 1994). On September 7, 1944, Japan suffered the defeat of the East Asian War so that the Japanese government would grant independence for Indonesia. For this reason, the Indonesian Independence Preparatory Agency (BPUPKI) was formed. BPUPKI consists of 62 people, including NU leaders (K.H. Wahid Hasyim and K.H. Masykur). Furthermore, 
NU was also involved in the "Panitia Sembilan," which formulated state philosophy. In this small committee, NU represented by K.H.Wahid Hasyim. The results agreed based on the State regarding "Godhead," coupled with the phrase " With the obligation to run Islamic Sharia for adherents." This decision is known as the "Jakarta Charter." But then, to maintain the integrity and unity of the nation, K.H. Wahid Hasyim proposed that the Jakarta Charter be replaced by "Ketuhanan yang Maha Esa".

On September 16, 1945, the Dutch army (NICA) arrived back in Indonesia, intending to regain control of Indonesia. Seeing this threat, NU immediately convened a Plenary session of the Big Management on October 22, 1945. At the meeting, the "Jihad Resolution" was issued, which obliged Muslims, especially NU members, to raise their weapons against the Dutch and their friends who wanted to re-colonize Indonesia. The resolution of this Jihad was indeed an inspiration for the arousal of the fighting spirit of Surabaya in the November 10, 1945 incident.

In the period 1960-1966, NU appeared to be a force against communism. This is done by forming several organizations, such as Banser (Multi-purpose Ansor Barisan), Lesbumi (Muslim Cultural Arts Institute), Pertanu (NU Peasant Association), and others. On October 5, 1965, NU demanded the dissolution of the PKI. NU started politics since joining with other Islamic community organization entities by forming Masyumi, chaired by K.H. Wahid Hasyim. Then NU became an independent political party in the 1955 election.

According to Fealy and Barton throughout the Sukarno period, NU gained a reputation for its flexible and accommodating political views. During the 1950-1960s, NU often changed its governmental policies to maintain its position in the government. Significant events that show that NU approved the dissolution of parliament and approved guided democracy from 1957 to 1959. During the PKI uprising in 1965, NU cooperated with the army in the bloody elimination of the Indonesian communist party and played a role in supporting the new order under the leadership of General Suharto (Van Bruinessen \& Wajidi, 1994).

During the old order of the NU also played a role in First, the holding of the election even in this election, NU won 45 seats in parliament (DPR). Second, the issuance of Government Regulation Number 10: limiting the economic activities of foreign entrepreneurs and encouraging indigenous entrepreneurs to develop. Third, the idea of the establishment of the Istiqlal mosque by K.H. A. Wahid Hasyim (then Minister of Religion) and approved by President Soekarno. Fifth, the realization of the translation of the Qur'an into Indonesian by the Minister of Religion, Prof. K.H. Syaifuddin Zuhri. Sixth, the organization of the Musabaqah Tilawatil Qur'an (MTQ) activities initiated by the Minister of Religion K.H. M. Dahlan. Seventh, the cancellation of the formation of the "Four-Leg Cabinet" (PNI-PKI-Masyu-mi-NU), direct resistance to PKI actions in all fields. The culmination of NU's opposition to the PKI was the failure of the PKI G30S. NU was listed as the first political party to propose to President Soekarno that the PKI dissolved. NU instigated this assertion on October 5, 1965, when Indonesian people were still skeptical about who was the architect of the G30S PKI (Gerakan 30 September Partai Komunis Indonesia).

According to Fealy and Barton, although initially, NU was a close associate of the new order regime, NU soon realized that she was a victim of the political de-Islamization of the new order. NU subjected to various restrictions and intimidation during the 1971 election. In 1973, NU forced to fuse with three other Islamic parties to form the United Development Party (PPP). During this period, NU was in opposition to the government. NU's involvement in politics came to a halt in 1984. 
The reason was that NU was increasingly marginalized in PPP and exhausted from government pressure, pushing NU out of PPP and returning to its original status as a religious, social organization. Since then, new leadership emerged within NU with its leading figure K.H. Achmad Siddiq and Abdurrahman Wahid. They stated that NU returned to the 1926 khittah, with more concentration on religious, social activities(Van Bruinessen \& Wajidi, 1994). At the moment, the dynamics of $\mathrm{NU}$ in the state are very pronounced, ranging from supporting to opposing the government. But NU is more concerned with religious, social movements because it returns to the khittah as a mass organization and is no longer a political party. In the end, $\mathrm{NU}$ was more flexible in taking its attitude and movements in building the NKRI.

Mitsuo Nakamura, through his writings entitled "Radical Traditionalism: Semarang Semarang Conference Note," clearly explains the political change of NU from 'opportunists' in the era of guided democracy (Soekarno) to radicalism in the new order. According to Mitsuo, the attitude of the NU organization depends very much on whether it feels that the existing political and social conditions are generally excellent or antipathic to Islamic values. For this reason, NU can work together with the Sukarno regime, which guarantees concessions to Islam, but opposes the Suharto regime, which they consider repressive and anti-Islamic(Van Bruinessen \& Wajidi, 1994). $\mathrm{NU}$, which is the largest Islamic mass organization in Indonesia, initially preferred a neutral stance before Suharto's resignation. But this attitude then changed after the Great Nahdlatul Ulama Board (PBNU) issued a view to responding to the reform process that took place in Indonesia, which is known as Reform Reflection.

This reform reflection contains eight points of the statement of attitude from PBNU, namely:

1. Nahdlatul Ulama has a moral responsibility to help keep reform going in a more appropriate direction,

2. National reconciliation carried out must be aimed at re-knitting ukhuwah wathaniyah (national brotherhood) and designed towards the structuring of a more democratic, honest and just national system and state,

3. Reform should not be stopped in the middle of the road so that it can reach the establishment of a new order in the life of the nation,

4. Delivering a wide range of ideas presented should be done with great care, full of wisdom and based on a shared commitment and the will to avoid their imposition,

5. Cases of human rights violations in the past must be addressed wisely and responsibly,

6. The TNI must stand above all groups,

7. The eradication of KKN must be done thoughtfully and not only for certain groups,

8. Monopolistic practices in Indonesia should be eradicated in any economic practices.

The role of $\mathrm{NU}$ in the post-reform era is very complicated in the political context. It seems that there is great hope to restore the glory of NU in the past. However, it is still too heavy if $\mathrm{NU}$ transformed into a political party. NU finally established the PKB, where PKB expected to be the only party that accessed the PBNU as well as the nahdhiyyin citizen party. At its peak in 1999-2000, all NU residents were proud because one of their cadres became the president of the Republic of Indonesia, namely K.H. Abdurrahman Wahid. But this did not last long because of pressures from the central axis coalition to bring down Gus Dur(Fernandes, 2019). After that event, PKB, by its development, seemed to be running on its own, sometimes even crossing with structural NU. Between PKB and NU began to look less harmonious, for example, PKB sacked its chairman Matori 
Abdul Jalil (for participating in signing Abdurrahman's reduction with another party) who disagreed with this. The NU-PKB discrepancy was heightened when NU nominated Hasyim Muzadi as Megawati Vice President (2004), but precisely at that time, the PKB supported Wiranto Wahid from Golkar, continued in the second round PKB election supporting SBY-JK. However, despite the dynamics of $\mathrm{NU}$ in the political context, $\mathrm{NU}$ played an active role in anticipating radical movements originating from the Islamic community itself or from outside and within the country.

To anticipate this in 2012, NU formed Laskar Aswaja to respond to concerns about religious-based radicalism. The handle used by NU so far has maintained the understanding of ahlus sunnah wal jama'ah (aswaja), which is adapted to the culture of the society in the frame of nationalism and the Unitary Republic of Indonesia. Prevent radical movements through da'wah movements and physically when forced to with the Aswaja Warriors. This was among the roles of $\mathrm{NU}$ in counteracting radicalism.

\section{CONCLUSION}

During the colonial period, there were two periods, namely the Netherlands and Japan. NU residents, the majority of whom are from pesantren, are fighting against the invaders. During the independence period, one NU figure who was a member of the BPUPKI participated in formulating the basis of the state, especially in the first precept. During the period of maintaining independence, NU held a Jihad Resolution, namely supporting the freedom of the Republic of Indonesia from the invaders. During the old order, Nakamura called NU "opportunist," but NU also played a role in holding the first elections in Indonesia. During the New Order era, according to Nakamura, it was 'radical' by returning to the khittah and no longer being a political party but as an Islamic organization. During the reform period, it was a momentum for NU to improve itself. In the postreform era, the dynamics of attraction between the NU-PKB color the NU history sheet in addition to $\mathrm{NU}$ also continuing to develop themselves until now.

From the discussion above, it can be concluded that the sociological and cultural contribution to the dynamics of the society in the NU religious movement can be illustrated that in politics, $\mathrm{NU}$ has a moral responsibility to oversee the reform agenda and maintain national stability with a variety of approaches in accordance with NU's mass culture.

This research, of course, is not an absolute conclusion, so it is still very open for subsequent researchers to conduct further studies. At least to provide one solution in providing correction to $\mathrm{NU}$ as an institution that is active in the social and religious fields.

\section{REFERENCES}

Bukhari, S. A. (2014). Kebangkitan Etnis Menuju Politik Identitas (A. Bainus (Ed.)). Yayasan Pustaka Obor Indonesia.

Fernandes, A. (2019). Politik Identitas Dalam Pemilu 2019 : Proyeksi Dan Efektivitas. Centre For Strategic And International Studies, 1, 1-10. Https://Www.Csis.Or.Id/Publications/PolitikIdentitas-Dalam-Pemilu-2019-Proyeksi-Dan-Efektivitas

Hemay, I., \& Munandar, A. (2016). Politik Identitas Dan Pencitraan Kandidat Gubernur Terhadap Perilaku Pemilih. Jurnal Politik Universitas Nasional, 12(1), 1737-1748. Http://Journal.Unas.Ac.Id/Politik/Article/View/163

Herdiansah, A. G. (2017). Politisasi Identitas Dalam Kompetisi Pemilu Di Indonesia Pasca 2014. Jurnal Bawaslu, 3(2), 169-183. Https://Jurnalbhumi.Stpn.Ac.Id/Index.Php/Jb/Article/View/121

Luthfi, A. N. (2017). Sejarah Dan Revitalisasi Perjuangan Pertanian Nahdlatul Ulama Melawan 
The Dynamics of the Role of the Nahdlatul Ulama Social Movement in Responding to Social Change Saepulah, Lina Herlina, Unang Fauzi

Ketidakadilan Agraria. Bhumi: Jurnal Agraria Dan Pertanahan, 3(2), 145-159. Https://Doi.Org/Https://Doi.Org/10.31292/Jb.V3i2.121.G122

Paralihan, H. (2019). Islam Dan Demokrasi: Menguatnya Politik Identitas Ancaman Kemanusiaan Di Indonesia. Aqlania Jurnal Filsafat Dan Teologi Indonesia, 10(1), 63-83. Https://Doi.Org/Http://Dx.Doi.Org/10.32678/Aqlania.V10i01.2109

Ridwan, N. K. (2008). Nu Dan Neoliberalisme : Tantangan Dan Harapan Menjelang Satu Abad (F. Mustafid (Ed.)). Lkis.

Syukur, A. (2011). Islam, Etnisitas, Dan Politik Identitas: Kasus Sunda. Miqot: Jurnal Ilmu-Ilmu Keislaman,

Juli-Desember 2011),

407-426.

Https://Doi.Org/Https://Doi.Org/10.30821/Miqot.V35i2.15

Van Bruinessen, M., \& Wajidi, F. (1994). Nu: Tradisi, Relasi-Relasi Kuasa, Pencarian Wacana Baru. Lkis. 